\title{
Social Competitiveness of the Youth and Their Perceptions of the Socio-Cultural Environment (Based on Research in a Large Siberian Region)
}

\author{
Valentin G. Nemirovskiy ${ }^{\mathrm{a}}$ \\ and Anna V. Nemirovskaya ${ }^{\mathrm{b} *}$ \\ ${ }^{a}$ Tyumen State University \\ 6 Volodarskogo Str., Tyumen, 625003, Russia \\ ${ }^{b}$ National Research University Higher School of Economics \\ 20 Myasnitskaya Str., Moscow, 101000, Russia
}

Received 26.12.2018, received in revised form 24.01.2019, accepted 06.02.2019

The purpose of the article is to analyse the social competitiveness of young people in the context of their ideas about their socio-cultural environment. The socio-cultural environment in the study is represented by the respondents' perceptions about the predominance of a certain type of society at three levels: Russia as a whole, the region, the enterprise (educational institution). The social competitiveness of young people has only scarcely been studied by sociologists. In the article, this phenomenon is seen as the ability of social actors to achieve their goals in a society in the conditions of competition with other people. The empirical basis of this research is a representative survey, conducted in 2016 in the Krasnoyarsk Territory using formalized interviews among 1000 respondents. The article shows that the most competitive youth are those who perceive their socio-cultural macro environment (Russian society) as either pre-industrial, feudal or industrial, capitalistic one. It is established that there are two opposing in their meaning forms of the moral and value environment of the young people in the region, each of which ensures the high social competitiveness of a certain part of the youth. In particular, the socio-cultural environment of the competitiveness of young people corresponds to the contemporary state of Russian society. On the contrary, many adult actors continue to live in the socio-cultural context of the past era. It is concluded that the socio-cultural environment of the activity is specific for various social actors, and the identification of mechanisms of determination of social success is a promising area for further research.

Keywords: social competitiveness, socio-cultural environment, value orientations, regional youth.

(C) Siberian Federal University. All rights reserved

* Corresponding author E-mail address: valnemirov@mail.ru; annanemirov@hse.ru ORCID: 0000-0002-4076-465X (Nemirovskiy); 0000-0003-2013-0964 (Nemirovskaya)

This work is licensed under a Creative Commons Attribution-NonCommercial 4.0 International License (CC BY-NC 4.0). 
The article was prepared within the framework of the state task of the Ministry of Education and Science of the Russian Federation "Formation of Competition-drivenness and Competitiveness among Russian Youth in the Context of Modern Socio-cultural Dynamics." Project No. 28.2941.2017/4.6 (project head-G.F. Shafranov-Kutsev, Academician of the Russian Academy of Education, Doctor of Philosophy, Professor, Scientific Director of the Tyumen State University).

Research area: sociology.

Citation: Nemirovskiy, V.G., Nemirovskaya, A.V. (2019). Social competitiveness of the youth and their perceptions of the socio-cultural environment (based on research in a large Siberian Region). J. Sib. Fed. Univ. Humanit. soc. sci., 12(2), 206-216. DOI: 10.17516/1997-1370-0389.

\section{Introduction}

Any modern society to varying degrees is built on competition between social actors. The objects of social competition are material goods, statuses, roles, power, prestige, and a lot of other things, which form the essence of our social life. Competitiveness of various socio-economic and other groups, strata, etc. is manifested quite clearly: the higher their social or economic status, the higher the competitive capabilities of its representatives, compared to those from other social groups. A more or less clear situation is also observed with such socio-demographic groups as men and women: gender differences, primarily in professional competitiveness, are widely recognized. The issue of the competitiveness of such an important socio-demographic group as young people (in this study people aged 18-25), especially in the context of a specific region, is less clear.

On the one hand, there are numerous facts of ageism in recruitment (at least in the Russian context). But it rather concerns their professional competitiveness. It is obvious that people from different social strata and groups have unequal social competitiveness due to their background. However, the latter is also largely determined by other sociocultural factors external to the actor (socio-cultural environment). The research problem lies in the lack of scientifically-based knowledge about the socio-cultural environment of the social competitiveness of the youth in the region as a socio-demographic group.

\section{Previous studies on the topic}

The socio-cultural environment has been extensively studied in Russian sociology within the framework of various areas of the socio-cultural approach. The study that characterizes it from the standpoint of the functional-genetic approach is among the few exceptions (Demidenko, 2002). Many definitions of the socio-cultural environment lack completeness, leaving its important elements aside. Thus, in some 
works it comes down to needs, interests, and value orientations; its social and socioeconomic factors are ignored (L’vova, 2011; Kanareva et al., 2016: 243). It is necessary to note the reasonability to include the intercultural factors in the education system of the multinational region where the research was conducted (Smolyaninova, 2016, Smolyaninova, 2018).

The most appropriate definition in the context of this phenomenon analysis is formulated from the standpoint of the socio-cultural approach: "The socio-cultural environment of the region is made up in the process of interaction between people under the influence of socio-economic, cultural, climatic and other factors, and represents the conditions that create people's motivation for daily life. Accordingly, it predetermines the choice of preferences, aspirations, and life position to ensure selfrealization and meeting the needs. It can be subjected to transformation in case of changing the development vector" (Shabunova, Okulova, 2011: 36). It will be used in this study as a working definition.

Social competitiveness is poorly studied in the both domestic and foreign scientific literature. In Russia, these are mainly studies by G.V. Vlasiuk, who considers it from the standpoint of the resource approach (Vlasiuk, 2013). According to the analysis of the peer-reviewed journals' databases, there is a lack of studies on the phenomenon of social competitiveness of young people in foreign and domestic academic papers. There is a mostly territorial aspect of the analysis, which, as a rule, is of applied nature. The social competitiveness provides not only social but also economic advantages for the region and its business interests, for instance, by creating a more socially sustainable investment environment (Haines-Young, Kretsch, Potschin, 2016).

Along with that, in many countries, the study of social competitiveness is an important area of comparative cross-country research, which is actively used in the field of management. In the late $20^{\text {th }}$ century "competitiveness" became as a fashionable concept as success or globalization, attracting the attention of both researchers, government circles and business organizations due to its connection with the success of organizations (Bhawsar, Chattopadhyay, 2015, et al.). Thus, a qualitative content analysis of the definitions of competitiveness published in 1998-2013 revealed that this concept is mostly associated with the enterprise or corporate level of the economy, a country or a nation as a whole (Olczyk, 2016).

The integral nature of the social competitiveness phenomenon determines the development of various indexes for its measurement. It stands to reason that the evaluation of competitiveness on the basis of aggregated statistical indicators with the 
further practical use of the results is widespread in modern foreign science. Thus, over the years, comparative measurements of the global sustainable competitiveness index have been carried out in the world (The Sustainable Competitiveness Report, 2016: 47). The World Economic Forum annually releases The Global Competitiveness Report, which assesses the drivers of productivity and prosperity of 138 countries of the world. According to the Report's methodology, competitiveness is defined as a set of institutions, policies, and factors that determine the level of economy productivity, forming the level of prosperity a country can achieve (The Global Competitiveness Report, 2016-2017: 20). Similarly, The Europe 2020 Competitiveness Report suggests a ranking of countries based on the competitiveness index that includes three dimensions, each of which is represented by a block of indicators: "smart" - enterprise environment, digital agenda, innovative Europe, education and professional training; "inclusiveness" - labor market and employment, social inclusion; and "sustainability" environmental sustainability (The Europe 2020 Competitiveness Report, 2014: 18).

In many countries, projects aimed at comparative studies of the young people's competitiveness and the processes of its formation are being implemented. For instance, Youth Competitiveness Indicator System in Hong Kong, launched in 2011 (Youth Competitiveness Indicator..., 2011: 2). Since 2015, the project of the European Commission Erasmus + Competitive European Youth has been implemented. It is aimed at young people aged 14-18 from 4 European countries (Spain, Hungary, Cyprus, and Lithuania), receiving education in ICT and project management (Competitive European Youth).

In Russian scientific literature devoted to competitiveness, in general terms it is possible to distinguish psychological and pedagogical, closely related to it sociopsychological, as well as economic and managerial approaches. The first two are focused on the consideration of competitiveness as a specific phenomenon, its structure, interrelations with other psychological constructs, the analysis of students' competitiveness development and the development of methods for its formation in the education system (mostly vocational) (Klyueva, 2016). The third one considers competitiveness as an important characteristic of an economic agent's activity at different levels: enterprise (firm) - industry - region - state, etc. (Vasil'eva, 2006, et al.).

\section{Research approach}

In this research social competitiveness is understood as the ability of a social actor to achieve his/her goals in the society under conditions of rivalry with other actors. In 
this case, the youth of a large Siberian region acts as such an actor. In the process of studying the socio-cultural environment, the authors of the present article are based on the area of the socio-cultural approach developed by N.I. Lapin and his colleagues.

The region "acts as a macrocell of the horizontal differentiation of the society and its socio-cultural space. This community forms a close socio-cultural environment for the activity of its members as individuals and motivates their actions; relationships between individuals are implemented in a complex and, in many respects, direct way and indirectly with the society" (Lapin, 2006: 25-26). The study of the young people's competitiveness in the region logically involves its comparison with another sociodemographic group - employable adults, their competitiveness and its socio-cultural environment. The complexity and multi-component nature of the socio-cultural environment do not give an opportunity to analyze all its diversity. It is important to emphasize that the socio-cultural environment was studied by the authors based on the respondents' ideas about its various elements that exist in the mass consciousness.

The authors put forward a hypothesis, in accordance with which young people who refer Russia as a whole, as well as their region, or enterprise (organization, educational institution) where they work (study) to a higher stage (type) of social development, have the highest social competitiveness.

\section{Research methods}

In this study, the authors proceeded from the notion that the social competitiveness of an actor is one of the functions of his/her human capital. At the same time, the results of its implementation are expressed by a number of indicators of subjective social well-being. Accordingly, the more developed the human capital of an individual or a social group, and the higher the subjective indicators that reflect the implementation of their competitive advantages in society, the higher the social competitiveness. The index method was used for its empirical research. It is commonly known that in its most general form, a sociological index is a tool for classification, comparison, and measurement, created by a combination of empirical indicators.

Based on the empirical indicators used to study the social competitiveness of young people and their socio-cultural environment, competitive respondents were selected using a specially developed by the authors composite "social competitiveness index" (SCI). The composite index is based on the indicators that characterize both the objective social position of the respondent and his/her subjective well-being. The first group includes the respondent's level of education (only options "incomplete 
higher education", "higher education (bachelor, specialist, master's degree)" and "postgraduate education (second university degree, postgraduate, etc.)" are used for the index); financial standing (answer options include "enough money for everything, but it is difficult to buy an apartment or a dacha" and "we don't limit ourselves to almost anything"), belonging to a certain social class ("upper class", "upper middle class" and "middle class") and the level of managerial authority ("11-50 people in submission", "51-100 subordinates" and "more than 100 subordinates"). The second one include satisfaction with their life in general ("fully satisfied" and "rather satisfied"), level of confidence in the future ("quite confident") and "rather confident than not") and assessment of the level of positivity or negativity of changes in the respondent and his family life compared to the last year ("started living much better" and "started living slightly better"). Each answer to the selected options is assigned 1 point, the sum of points for the respondent is divided by the number of variables (7). As a result, individual index values are distributed from 0 to 1 . The SCI value indicates the level of social competitiveness of an individual.

The survey, which data formed the basis of the article, was carried out by the sociologists of Siberian Federal University in 28 settlements of the Krasnoyarsk Territory in February 2016 and was proactive. It was carried out by the method of semistructured interviews at the places of the respondents' residence by the stratified, multistage, regionalized, quota sampling, represented by the age and gender, education and settlement structure of the region; 1000 people were interviewed. In the course of the study, a subsampling of the respondents corresponding to the competitiveness criteria developed in the study was formed in the general data set to test the hypothesis, which in general amounted to 509 people, i.e., almost half of the respondents.

\section{Results and discussion}

It is a well-known fact that from a scientific point of view, the issue of the type of society that currently exists in our country is rather controversial. However, social actors act by their ideas and life experience, rather than materials of scientific discussions. In the course of the study, a correlation of the respondents' SCI with their answers to the question "Features and characteristics of which of the traditionally distinguished types of society prevail in the Krasnoyarsk Territory, in your opinion?" has been identified. The respondents were asked to assess the predominance of the following types of societies: information, post-capitalist; industrial, capitalist; pre-industrial, feudal and slave-owning using a four-point scale ("to a great extent", "to a considerable 
extent", "only partially", "absent", and "not sure"). At the same time, three levels of the sociocultural environment of the respondents have been identified:

- Russia as a whole,

- the region where they live (the Krasnoyarsk Territory),

- the enterprise where they work.

According to the correlation analysis results, young people who evaluate the sociocultural environment in Russia as a manifestation of an earlier, pre-industrial stage of development have higher CSI; the average CSI value among those who chose feudal society is 0.60 , while the CSI of those who noted that "The information and postcapitalist society fully prevails in Russia" is 0.47 , and "the industrial and capitalist society -0.49 ". There is also a correlation between these variables, the ideas about the pre-industrial society predominance in the country and the level of the respondent's personal competitiveness (Spearman coefficient, 201*), and ideas about Russian society as industrial and capitalist, SCI is $0.191^{*}$ ) (hereinafter, the * sign indicates statistical significance at the level 0.05 , the $* *$ sign indicates statistical significance at the level 0.01).

Young people are included in the socio-cultural environment of the Krasnoyarsk Territory and interact with it more directly. It is possible to distinguish two ideas related to the level of these respondents' competitiveness in the mass consciousness of young people: 1) the opinion that the features and characteristics of the industrial and capitalist society prevail in the Krasnoyarsk Territory $\left(, 175^{*}\right) ; 2$ ) the idea that the respondents already live in the region in the conditions of the information and postcapitalist society $(, 153 *)$.

On the contrary, the ideas that the features and characteristics of the slave-owning society predominate at the enterprise where the respondents work are related to the negative SCI correlation: -,297**.

\section{Conclusion}

The obtained results indicate that the hypothesis put forward by the authors has been partially confirmed, the study results are ambiguous. More competitive young people are inclined to perceive the socio-cultural environment in Russia as a whole as a manifestation of the pre-industrial, feudal, and partially capitalist society. Regarding the ideas about the socio-cultural environment of the region, two trends has been revealed: according to the first one, more competitive respondents more often evaluate it as a manifestation of the industrial and capitalist society, and according to the second 
one (somewhat weaker), as a characteristic of the information and post-capitalist society. It can be assumed that it is referred to two subgroups of the competitive youth that use competitive strategies characteristic of each of these types of societies. Modern Russian society (like any other) is quite complex and contradictory; it contains elements, lacunae, and fluctuations that can be attributed to various formations. Accordingly, the most competitive actors are those who use competitive strategies that best correspond to the specific features of the social relations which they are included in. The perceptions that the features and characteristics of the slave-owning society predominate at the enterprises where the respondents work have a rather high negative correlation with their competitiveness index. It is clear that employment in organizations where working conditions and corporate culture cause an analogy with slave labor among young employees, leads to their low competitiveness in modern society. At the same time, the fact that low competitive employees are often recruited to such enterprises cannot be ignored.

The richest phenomenon of the socio-cultural environment of the young people's social competitiveness undoubtedly requires further research, including based on the more extensive empirical material, with the use of the inter-regional comparative approach.

\section{References}

Bhawsar P., Chattopadhyay U. (2015). Competitiveness: Review, Reflections and Directions, In Global Business Review, 16 (4), 665-679.

Competitive European Youth. Erasmus + Programme. European Commission. Available at: http://ec.europa.eu/programmes/erasmus-plus/projects/eplus-projectdetails/\#project/a37fa300-36d9-447f-8912-e36d934bdc33 (Accessed 20.06.2018).

Demidenko, S.V. (2002). Razvitie sotsiokul'turnoi sredy sovremennogo rossiiskogo goroda [Development of the Socio-Cultural Environment of the Modern Russian City]. Dissertation for the Degree of the Candidate of Sociological Sciences. Rostov-on-Don, 194 p.

Haines-Young, R., Kretsch, C. and Potschin, M. (2016). Competitiveness, In Potschin, M. and K. Jax (eds): OpenNESS Ecosystem Services Reference Book. EC FP7 Grant Agreement no. 308428. Available at: www.openness-project.eu/library/referencebook; http://www.openness-project.eu/sites/default/files/SP-Competitiveness.pdf (Accessed 20.06.2018).

Kanareva, N.A., Balavich, P., Karfidova, T.N. (2016). Izuchenie i formirovanie sotsiokul'turnoi sredy regiona s uchetom dosugovykh predpochtenii sovremennoi 
molodezhi [Study and Formation of the Socio-Cultural Environment of the Region, Taking Into Account Leisure Preferences of the Modern Youth], In Innovatsionnyi potentsial molodezhi: globalizatsiia, politika, integratsiia: sbornik statei uchastnikov Mezhdunarodnoi molodezhnoi nauchno-issledovatel'skoi konferentsii (Ekaterinburg, 25-26 Oktiabria 2016 goda) [Innovative Potential of the Youth: Globalization, Politics, Integration: collected works of the participants of the International Youth Scientific and Research Conference (Ekaterinburg, October, 25-26, 2016)]. Ekaterinburg, Ural University Publishing House, 242-249.

Klyueva, O.A. (2016). Competitiveness of Personality as a Psychological Phenomenon: The Content of the Construct and its Typology, In Psychology in Russia: State of the Art, 9 (2). Lomonosov Moscow State University: Russian Psychological Society, 151-156.

Lapin, N.I. (2006). Region, ego status i funktsii v rossiiskom obshchestve: teoretikometodologicheskie osnovy issledovaniia [Region, Its Status and Functions in the Russian Society: Theoretical and Methodological Research Basis], In Sotsiologicheskie issledovaniia [Sociological Studies], 8, 25-34.

L'vova. I.G. (2011). K voprosu o sushchnosti poniatiia "sotsiokul'turnaia sreda" [To the Issue of the Essence of the Concept of "Socio-Cultural Environment"], In Kul'tura i faktory ee innovatsionnogo razvitiia: Sbornik statei. Nauch. red. E.V. Mareeva, V.A. Tikhonova, S.A. Kasatkina [Culture and Factors of Its Innovative Development: Collected Articles. Science editors E.V. Mareeva, V.A. Tikhonova, S.A. Kasatkina]. M., MSIC, 39-43.

Olczyk, M.A. (2016). Systematic Retrieval of International Competitiveness Literature: A Bibliometric Study, In Eurasian Economic Review, 6 (3), 429-457.

Shabunova, A.A., Okulova, N.A. (2011). Otsenka naseleniem sotsiokul'turnoi sredy regiona [Assessment of the Socio-Cultural Environment of the Region by Population], In Sotsiologicheskie issledovaniia [Sociological Studies], 6, 36-43.

Smolyaninova, O.G. (2016). Intercultural Educational Platform and PL2S Center for Developing Tolerance of Krasnoyarsk Region Citizens. [Proc. Edulearn16 Conference]. Barcelona, 1005-1013.

Smolyaninova, O.G. (2018). Mediation Practices, In Education: Intercultural Contexts of Multinational Siberia. [Proc. 10th International Conference on Education and New Learning Technologies]. Palma, Mallorca, 3862-3867.

The Global Competitiveness Report 2016-2017. Ed. Klaus Schwab. World Economic Forum. Available at: https://www.weforum.org/reports/the-global-competitivenessreport-2016-2017-1 (Accessed 20.06.2018) 
The Europe 2020 Competitiveness Report. Building a More Competitive Europe. Insight Report. 2014. World Economic Forum. Available at: http://www3.weforum.org/ docs/WEF_Europe2020_CompetitivenessReport_2014.pdf (Accessed 20.06.2018)

The Sustainable Competitiveness Report, $5^{\text {th }}$ Edition. September 2016. SolAbility Sustainable Intelligence. Zurich, Seoul. 57 p.

Vasil'eva, Z.A. (2006). Ierarkhiia poniatii konkurentosposobnosti sub"ektov rynka [Hierarchy of the Concepts of Market Participants' Competitiveness], In Marketing v Rossii $i$ za rubezhom [Marketing in Russia and Abroad], 2, 83-90.

Vlasiuk, G.V. (2013). Konkurentosposobnost'. Sotsiologicheskii aspekt [Competitiveness. Sociological Aspect.]. M., Nauchnye tekhnologii, 166 p.

Youth Competitiveness Indicator System in Hong Kong. Available at: http:// www.coy.gov.hk/filemanager/template/common/images/archive/research/youth_ report_2012s_e.pdf (Accessed 20.06.2018).

\title{
Социальная конкурентоспособность молодежи \\ и ее представления о социокультурной среде \\ (на материалах исследования \\ в крупном Сибирском регионе)
}

\author{
В.Г. Немировский ${ }^{\mathbf{a}}$, А.В. Немировская ${ }^{\sigma}$ \\ атюменский государственный университет \\ Россия, 625003, Тюмень, ул. Володарского, 6 \\ ${ }^{6}$ Национальный исследовательский университет \\ «Высшая школа экономики» \\ Россия, 101000, Москва, ул. Мясницккая, 20
}

Цель статьи состоит в анализе социальной конкурентоспособности молодежи в контексте ее представлений о своей соииокультурной среде. Социокультурная среда в исследовании репрезентирована представлениями респондентов о преобладании определенного типа общества на трех уровнях: Россия в целом, регион, предприятие (учебное заведение). Сочиальная конкурентоспособность молодежи практически не изучена отечественными социологами. Данный феномен в статье трактуется как способность сочиального актора к достижению своих иелей в обществе в условиях соперничества с другими. Эмпирической базой выступает исследование, проведенное в 2016 г. в Красноярском крае по репрезентативной выборке методом формализованного интервью среди 1000 респондентов. В статье показано, что наиболее конкурентоспособна та молодежь, которая воспринимает свою социокультурную макросреду (российское общество в целом) как доиндустриальное, феодальное или индустриальное, 
капиталистическое. Авторы делают предположение, что сочиокультурная среда конкурентоспособности молодежи максимально соответствует современному состоянию российского общества, что влечет за собой вывод о специфичности социокультурной среды деятельности различных социальных акторов и перспективности ее дальнейшего исследования для выявления малоизученных механизмов детерминации их соииальной успешности.

Ключевые слова: сочиальная конкурентоспособность, сочиокультурная среда, иенностные ориентации, молодежь региона.

Статья подготовлена в рамках выполнения государственного задания Минобрнауки $P Ф$ «Формирование конкурентоориентированности и конкурентоспособности молодежи в российском обществе в контексте современной сочиокультурной динамики». Код проекта 28.2941.2017/4.6 (руководитель — академик Российской академии образования, доктор философских наук, профессор, научный руководитель Тюменского государственного университета Г.Ф. Шафранов-Куцев).

Научная специальность: 22.00.00 - социиологические науки. 